\title{
Brazil - Case Comment - Internet Domain Name "aol.com.br" - The Leading Case
}

\author{
Luir Edgand e Mlantauxy Pimenta
}

Partner of the Law Firm of Montaury Pimenta, Machado \& Lioce, Rio de Janeiro, Brazil.

Domain Names can be registered in Brazil by any Brazilian Company regularly established in the country. This type of registration is made at FAPESP, which is the Agency responsible for the Internet Domain Name registrations in Brazil, in view of a delegation of competency determined by the Brazilian Ministry of Industry and Commerce. This Domain Name registration procedure is very simple, and any company regularly established in the country is able to obtain up to ten Domain Name registrations.

Since opposition procedures are not available at FAPESP, the only alternative to request the cancellation of a Domain Name registration is to send warning-cease and desist letters to the titleholder of the registration and to FAPESP, and if the registration is not assigned and/or canceled, the remaining alternative is to file a court action at a Brazilian Federal Court seeking the cancellation of that Domain Name registration.

In the Brazilian Courts this is a new issue, since no cases were taken into Court up to very recently.
On April 1997, the Brazilian Company AMERICA ON LINE TELECO. MUNICAÇÕES LTDA., established in the city of Curitiba, State of Paraná, an Internet Service Provider, has started using the marks "AOL" and "AMERICA ONLINE" to distinguish its Internet Services and registered the Domain Name "AOL.COM.BR" at FAPESP. A warningcease and desist letter has been sent to such company by AMERICA ONLINE INC., but same refused to assign such rights alleging only that the accent inserted in the word "América" would be an evidence that they were not acting with bad faith and that their clients would never confuse the services with those provided by the U.S. company AMERICA ONLINE INC. Another warning-cease and desist letter was sent to FAPESP which refused to cancel the Domain Name registration, without major explanations.

AMERICA ONLINE INC. then decided to file a court action against both AMÉRICA ON LINE TELECOMUNICA. ÇÕES LTDA. and FAPESP at a Federal 
Court in the city of Curitiba, State of Paraná (where AMÉRICA ON LINE TELECO. MUNICAÇÕES LTDA. is located), and the $10^{\text {th }}$ Section of the Federal Court of the city of Curitiba has granted a preliminary injunction on January 26, 1999, in which FAPESP has been sentenced to suspend the divulgation and publication of the "AOL.COM.BR" domain name in the Internet, and the suspension of such registration until the final decision of the court action is rendered, and AMÉRICA ON LINE TELECOMUNICAÇÕES LTDA. has been sentenced to, besides ceasing the use of the marks "AMERICA ONLINE" and "AOL", to also cease the use of the domain name "AOL.COM.BR" until the final decision of the court action.

Under the Brazilian Law, there are two basic requirements to be met in order to enable the Judge to grant a preliminary injunction decision, i.e., to present strong evidences of Plaintiff's rights and the suspicion of irreparable damages.

The first basic condition has been duly demonstrated by AMERICA ONLINE INC. by means of submitting copies of several certificates of registration for the marks "AOL", "AMERICA ONLINE" and their corresponding logos as well as proving the notoriety of these marks by means of presenting copies of U.S. and other countries' registrations for these marks, advertisements and articles published in Brazilian publications as well as in magazines of international circulation.

The recent enacted Brazilian Intellectual Property Law has placed Brazil in a more confortable position in relation to the protection of intellectual property rights on a world-wide scenario, trying to put aside the previous negative image, which for a long time has prevailed (in the sense of allowing the practice of trademark piracy).

The above mentioned evidences also proved, in this case, that Plaintiff's marks are well-known in relation to Internet services, entitling AMERICA ONLINE INC. to benefit from the provisions established in Section 126 of the Brazilian Trademark Law, which states:

"Article 126 - Marks that are well-known in their field of activity in the terms of article 6 bis (1) of the Paris Convention for the Protection on Industrial Property will enjoy special protection, independently of whether they have been previously filed or registered in Brazil."

As to the suspicion of irreparable damages or damages of difficult reparation in this case, which is the other necessary requirement to allow the grant of preliminary injunctions, Plaintiff has cleared proved that the first Defendant was using Plaintiff's domain name and marks in the Internet and consequently risking the international reputation of this mark and Domain Name. Furthermore, the users may think that they were using the services of one company when, in fact, they were being supplied by another company, which does not have any relation with the Plaintiff.

Another strong argument used in this case was that while the Brazilian company AMÉRICA ON LINE TELECO. MUNICAÇÕES LTDA. was using the
"AOL" mark as part of its domain name, AMERICA ONLINE, INC. would not be able to use it at the Internet in Brazil, which would probably cause high losses and damages.

Besides the preliminary injunction request, that has been granted by the Judge due to the unquestionable existence of these two pre-requisites, this court action also claims the payment of losses and damages, by the first Defendant, which according to this recently enacted Law, should be calculated on the basis of the benefits that the injured party would have gained, in case the violation had not occurred.

Loss of profits are to be determined by the most favorable criteria to the injured party, on the basis of: a) the benefits that the injured party would have gained if the violation had not occurred; b) the benefits gained by the Defendant in the situation in question; or c) the remuneration that the Defendant would have paid to the Plaintiff for a granted license which would have legally permitted him to exploit the subject of the rights.

This decision is extremely important, since this is to be considered the leading case for Internet Domain Name registrations in Brazil and what is definitely most important, is the fact that a preliminary injunction decision has been granted, thus suspending, immediately, the Internet address "AOL.COM.BR"

In Brazil, some companies or individuals have registered domain names at FAPESP containing third party's well known names and marks, to try to sell the rights arising from such Domain Name registrations to their corresponding legitimate owners, usually asking for a considerable amount of money, what could be called "Domain Name Piracy".

Some companies have been settling agreements with these Pirate-Infringers, and in order to recover their own Domain Names are giving them a sum of money in exchange for the assignment of their Domain Name registrations. This practice created a truly gray market in which the actual owner of the Domain Name usually decides to pay considerable amounts of money due to the delay and backlog of the Brazilian Courts to render final decisions in relation to such type of cases.

Some well-known marks have been registered as Domain Names at FAPESP in Brazil by unauthorized parties such as "firestone.com.br", "redley.com.br", "hardrock.com.br", "altavista.com.br", "burgerking.com.br", and this recent decision concerning the Domain Name "AOL.COM.BR" can certainly be used as an extremely helpful tool to revert the situation of these and other similar cases in Brazil. 